\title{
Faktor Prognostik Kematian Bayi Berat Lahir Sangat Rendah di Rumah Sakit Rujukan Tingkat Tersier
}

\author{
Tunjung Wibowo, Ekawaty Lutfia Haksari, Setya Wandita \\ Bagian Ilmu Kesehatan anak Fakultas Kedokteran Universitas Gadjah Mada/RSUP Dr. Sardjito, Yogyakarta
}

\begin{abstract}
Latar belakang. Bayi berat lahir sangat rendah (BBLSR) masih merupakan tantangan dalam upaya menurunkan angka kematian neonatal. Beberapa faktor risiko telah terbukti meningkatkan risiko kematian BBLSR, seperti berat lahir dan umur kehamilan. Besarnya variasi tingkat perawatan di neonatal intensive care unit (NICU) juga akan berkontribusi terhadap risiko kematian.

Tujuan. Melakukan pengaruh beberapa faktor maternal, fetal, kondisi bayi dan parameter pemeriksaan pendukung terhadap kematian BBLSR.

Metode. Penelitian kohort prospektif dilakukan di bangsal Perinatologi RSUP Dr. Sardjito Yogyakarta dari tanggal 1 Februari 2007 sampai Agustus 2010. Semua bayi yang dirawat dengan berat lahir lebih dari 500 g, tanpa kelainan kongenital yang lethal dan dapat diikuti sampai diijinkan pulang dimasukkan sebagai subjek penelitian. Data faktor prognostik kematian dikumpulkan dengan formulir yang sudah terkode. Dilakukan analisis dengan logistik regresi untuk mengetahui pengaruh faktor prognosis terhadap kejadian kematian BBLSR.

Hasil. Didapatkan 394 bayi lahir BBLSR yang diikutsertakan ke dalam penelitian, 33 (8\%) bayi dikeluarkan karena pulang sebelum diijinkan. Angka kematian BBLSR 62,3\%. Dari hasil analisis multivariat didapatkan variabel yang dapat menjadi faktor prognostik kematian BBLSR adalah berat lahir $<1000 \mathrm{~g}$ ( OR:5; 95\% CI: 2,3 - 10,7), nilai Apgar menit pertama <4 (OR: 6: 95\% CI: 3,1 - 12), penggunaan ventilator (OR; 8,3; 95\% CI: 4,3-16), sepsis (OR: 12; 95\% CI: 3,8 - 37,9) dan kasus rujukan (OR: 3,1; 95\% CI: 1,4 - 6,6) Kesimpulan. Berat lahir $<1000 \mathrm{~g}$, nilai Apgar menit pertama $<4$, penggunaan ventilator, sepsis dan kasus rujukan merupakan faktor prognostik yang secara bermakna meningkatkan kematian BBLSR. Sari Pediatri 2012;13(6):401-5.
\end{abstract}

Kata kunci: prognostik, sepsis, ventilator

Alamat korespondensi:

Dr. Tunjung Wibowo, MPH, M.Kes, Sp.A. Bagian Ilmu Kesehatan anak Fakultas Kedokteran Universitas Gadjah Mada/ RSUP Dr. Sardjito , Jl Kesehatan No. 1, Sekip, Yogyakarta, Telp: (0274) 541565, fax: (0274) 541565. E-mail: tunjungwibowo@yahoo.com
I nsidens bayi berat lahir sangat rendah (BBLSR) diperkirakan 4\%-7\% dari total kelahiran hidup, tetapi dalam perawatannya kelompok bayi tersebut memerlukan sumber daya yang besar. Angka kematian BBLSR bervariasi antara 57\% di 
negara berkembang dan $10 \%$ di negara maju. ${ }^{1-3} \mathrm{Di}$ negara maju angka harapan hidup BBLSR meningkat sangat dramatis, kondisi ini mungkin karena kemajuan bidang perinatal-neonatal, penanganan kehamilan risiko tinggi, dan kemajuan resusitasi pada BBLSR. ${ }^{3,4}$

Studi terdahulu menunjukkan bahwa peningkatan berat lahir sangat berhubungan dengan kesintasan BBLSR sedangkan keparahan penyakit berhubungan terbalik dengan kemampuan BBLSR untuk bertahan hidup, ${ }^{5,6}$ tetapi faktor tersebut saja tidak dapat menerangkan variasi angka kematian di beberapa NICU. Interaksi antara keparahan penyakit dan perubahan fisiologis akan mempengaruhi manajemen sehingga akan mempengaruhi keluaran penyakit sehingga diperlukan suatu usaha untuk menentukan parameter fisologis maupun laboratoris yang dapat menjadi faktor prediktor kematian BBLSR. ${ }^{7}$ Penelitian bertujuan untuk mengetahui pengaruh beberapa faktor maternal, fetal, kondisi bayi, dan parameter pemeriksaan pendukung terhadap kematian BBLSR.

\section{Metode}

Telah dilakukan penelitian kohort prospektif yang bertujuan untuk membuat registrasi data mortalitas dan morbiditas semua bayi baru lahir yang dirawat di bangsal perawatan bayi RSUP Dr. Sardjito Yogyakarta. Penelitian merupakan kerjasama dengan WHO-SEARO Collaborating Center. Data tentang identitas, riwayat kehamilan dan persalinan, resusitasi bayi baru lahir, kelainan kongenital, morbiditas yang meliputi infeksi, asfiksia, pemberian minum, hiperbilirubinemia, kelainan metabolik, dan masalah pada bayi prematur, serta mortalitas dikumpulkan dengan kuesioner yang sudah terkode. Penelitian mulai dilakukan pada tanggal 1 Februari 2007 dan sampai Agustus 2010. Pengumpulan data dilakukan oleh dua orang perawat berdasarkan data dari rekam medis. Sebelum penelitian dimulai, perawat tersebut dilatih untuk melakukan pengisian formulir penelitian. Uji coba pengisian formulir dan dokumentasi data ke dalam komputer dilakukan selama sebulan sebelum penelitian dimulai.

Subyek penelitian adalah semua bayi yang dirawat di bangsal Perinatologi RSUP Dr. Sardjito terdiri dari bayi berasal dari rujukan rumah sakit lain dan bayi yang lahir di Rumah Sakit Dr. Sardjito. Bayi dengan berat badan kurang dari 500 g, bayi dengan kelainan kongenital yang letal, atau pulang sebelum diijinkan tidak diikutsertakan pada penelitian.

Setiap bayi yang lahir di rumah sakit Dr.Sardjito ditimbang berat badannya dengan menggunakan alat penimbang berat badan digital SECA model 727 , sedangkan data berat badan bayi rujukan didapatkan dari surat rujukan atau ditanyakan langsung ke rumah sakit yang merujuk. Bayi akan dikelompokkan dalam kelompok berat badan lahir sangat rendah (BBLSR) apabila berat badan kurang dari $1500 \mathrm{~g}$. Nilai Apgar dinilai oleh dokter yang melakukan resusitasi pada menit ke-1, 5, dan 2 jam, sedangkan sumber data nilai Apgar adalah surat rujukan atau komunikasi langsung dengan petugas yang melakukan resusitasi. Diagnosis penyakit membran hialin $(\mathrm{PMH})$ ditegakkan berdasarkan gambaran retikulogranular dan air bronchogram pada foto thoraks. Bayi didiagnosis menderita sepsis apabila pada biakan darah tumbuh mikroorgamisme.

Data yang sudah dikumpulkan disimpan dalam komputer, pengecekan data dilakukan secara berkala untuk menjamin validitas data yang dikumpulkan. Analisis dilakukan dengan menggunakan program statistik. Uji Chi square dilakukan untuk menghitung perbedaan proporsi. Odds ratio (OR) dengan interval kepercayaan (IK) 95\% dihitung untuk mengetahui pengaruh variabel bebas terhadap variabel tergantung. Analisis multivariabel dilakukan untuk mengontrol variabel pengganggu.

\section{Hasil}

Jumlah bayi yang dirawat di bangsal Perinatologi RSUP Dr. Sardjito selama kurun waktu penelitian ini adalah 7153 bayi baru lahir, 2041 (28,5\%) di antaranya adalah bayi rujukan. Didapatkan 394 (5,5\%) adalah BBLSR, dan 33 (8\%) BBLSR pulang atas permintaan sendiri sehingga dikeluarkan dari penelitian karena kesulitan untuk melacak kondisi akhir bayi. Di antara 361 bayi BBLSR yang mempunyai data sampai diijinkan pulang, terdapat 89 bayi dengan berat badan lahir kurang dari $1000 \mathrm{~g}$ atau berat badan lahir ekstrim rendah (BBLER), sedangkan bayi dengan berat badan kurang dari 1500 sampai 1000 g adalah 272 . Bayi BBLSR 225 orang di antaranya bertahan hidup sehingga survival BBLSR 62,3\%. Di antara 35 (39,3\%) BBLER mampu bertahan hidup sampai pulang, 
Tabel 1. Karakteristik subyek penelitian

\begin{tabular}{|c|c|c|c|}
\hline Karakteristik & $\begin{array}{l}\text { Hidup } \\
(\mathrm{n}=225)\end{array}$ & $\begin{array}{l}\text { Meninggal } \\
(\mathrm{n}=136)\end{array}$ & $\begin{array}{c}\text { Uji hipotesis } \\
\text { p* }^{*}\end{array}$ \\
\hline \multicolumn{4}{|c|}{ Berat badan lahir (n,\%) } \\
\hline BBLER & $35(39,1)$ & $54(60,7)$ & \multirow[t]{2}{*}{0,000} \\
\hline BBLSR & $190(69,9)$ & $82(30,1)$ & \\
\hline \multicolumn{4}{|l|}{ Jenis kelamin } \\
\hline Laki-laki & $108(63,5)$ & $62(36,5)$ & \multirow[t]{2}{*}{0,65} \\
\hline Perempuan & $117(61,3)$ & $74(38,7)$ & \\
\hline \multicolumn{4}{|l|}{ Umur ibu (tahun) } \\
\hline$<20$ & $10(43,5)$ & $13(56,5)$ & \multirow[t]{2}{*}{0,05} \\
\hline$>20$ & $215(63,6)$ & $123(36,4)$ & \\
\hline \multicolumn{4}{|l|}{ Cara persalinan } \\
\hline Seksio sesaria & $92(72,4)$ & $35(27,6)$ & \multirow{2}{*}{0,003} \\
\hline Lahir spontan & $133(56,8)$ & $101(43,2)$ & \\
\hline \multicolumn{4}{|c|}{ Nilai Apgar menit pertama } \\
\hline$<4$ & $46(37,4)$ & $77(62,6)$ & \multirow{2}{*}{0,000} \\
\hline$>4$ & $154(77)$ & $46(23)$ & \\
\hline \multicolumn{4}{|c|}{ Persalinan kembar/multipel } \\
\hline Ya & $12(52,2)$ & $11(47,8)$ & \multirow{2}{*}{0,3} \\
\hline Tidak & $213(63)$ & $125(37)$ & \\
\hline \multicolumn{4}{|c|}{ Penyakit membran hialin } \\
\hline Ya & $58(46,4)$ & $67(53,6)$ & \multirow[t]{2}{*}{0,000} \\
\hline Tidak & $167(70,8)$ & $69(29,2)$ & \\
\hline \multicolumn{4}{|c|}{ Menggunakan ventilator } \\
\hline Ya & $47(31,3)$ & $103(68,7)$ & \multirow[t]{2}{*}{0,000} \\
\hline Tidak & $178(84,4)$ & $33(15,6)$ & \\
\hline \multicolumn{4}{|l|}{ Sepsis } \\
\hline $\mathrm{Ya}$ & $5(11,1)$ & $40(88,9)$ & \multirow[t]{2}{*}{0,000} \\
\hline Tidak & $220(69,6)$ & $96(30,4)$ & \\
\hline \multicolumn{4}{|l|}{ Kasus rujukan } \\
\hline $\mathrm{Ya}$ & $72(53,7)$ & $62(46,3)$ & \multirow{2}{*}{0,01} \\
\hline Tidak & $153(67,4)$ & $74(32,6)$ & \\
\hline
\end{tabular}

*Uji chi square

sedangkan bayi dengan berat lahir 1000 - 1500 g yang bertahan hidup sampai pulang 190 (70\%).

Rerata berat badan bayi yang bertahan hidup adalah $1229 \mathrm{~g}(\mathrm{SD} \pm 266)$, lebih tinggi dibandingkan rerata berat badan bayi yang meninggal, yaitu $1029 \mathrm{~g}$ $(\mathrm{SD} \pm 292)$ dan secara statistik bermakna $(\mathrm{p}<0,001)$. Data tentang karakteristik subyek penelitian tertera pada Tabel 1.

Pada analisis regresi logistik bivariat faktor prognosis yang bermakna mempengaruhi terjadinya kematian adalah berat badan lahir, cara persalinan, nilai Apgar menit pertama $<4$, penyakit membran hialin, penggunaan ventilator, sepsis, dan kasus rujukan. Nilai
OR dan IK untuk masing-masing faktor prognosis tertera pada Tabel 2 .

Tabel 2 memperlihatkan variabel yang dimasukkan dalam model analisis multivariat adalah variabel yang bermakna secara statistik dalam analisis bivariat, yaitu berat badan lahir, cara persalinan, nilai Apgar menit pertama, penyakit membran hialin, penggunaan ventilator, sepsis dan faktor rujukan. Setelah dimasukkan dalam model analisis multivariat, variabel yang masih bermakna meningkatkan risiko terjadinya kematian pada BBLSR adalah berat badan lahir $<1500$ g, Nilai Apgar menit pertama $<4$, bayi yang menggunakan ventilator, bayi yang menderita sepsis dan kasus rujukan. 
Tabel 2. Faktor prognostik kematian BBLSR

\begin{tabular}{|c|c|c|c|c|}
\hline \multirow{2}{*}{ Karakteristik } & \multicolumn{2}{|c|}{ Analisis bivariat } & \multicolumn{2}{|c|}{ Analisis multivariat } \\
\hline & OR & $95 \%$ IK & OR & $95 \%$ IK \\
\hline \multicolumn{5}{|c|}{ Berat badan lahir (gram,n,\%) } \\
\hline BBLSR & 1 & & 1 & \\
\hline BBLER & 3,6 & $2,2-5,9$ & 5 & $2,3-10,7$ \\
\hline \multicolumn{5}{|l|}{ Jenis kelamin } \\
\hline Laki-laki & 1 & & & \\
\hline Perempuan & 1,1 & $0,7-1,7$ & & \\
\hline \multicolumn{5}{|l|}{ Umur ibu (tahun) } \\
\hline$>20$ & 1 & & & \\
\hline$<20$ & 2,3 & $1-5,3$ & & \\
\hline \multicolumn{5}{|l|}{ Cara Persalinan } \\
\hline Seksio sesaria & 1 & & 1 & \\
\hline Lahir spontan & 2 & $1,3-3,2$ & 1,4 & $0,7-2,9$ \\
\hline \multicolumn{5}{|c|}{ Nilai Apgar menit pertama } \\
\hline$>4$ & 1 & & 1 & \\
\hline$<4$ & 5,6 & $3,4-9,2$ & 6 & $3,1-12$ \\
\hline \multicolumn{5}{|c|}{ Persalinan kembar/multipel } \\
\hline Tidak & 1 & & & \\
\hline Ya & 1,6 & $0,7-3,7$ & & \\
\hline \multicolumn{5}{|c|}{ Penyakit membran hialin } \\
\hline Tidak & 1 & & 1 & \\
\hline Ya & 2,8 & $1,8-4,4$ & 1,2 & $0,6-2,4$ \\
\hline \multicolumn{5}{|c|}{ Menggunakan ventilator } \\
\hline Tidak & 1 & & 1 & \\
\hline $\mathrm{Ya}$ & 11,8 & $7,1-19,6$ & 8,3 & $4,3-16$ \\
\hline \multicolumn{5}{|l|}{ Sepsis } \\
\hline Tidak & 1 & & 1 & \\
\hline $\mathrm{Ya}$ & 18,3 & $7-47,9$ & 12 & $3,8-37,9$ \\
\hline \multicolumn{5}{|l|}{ Kasus rujukan } \\
\hline Tidak & 1 & & 1 & \\
\hline $\mathrm{Ya}$ & 1,8 & $1,2-2,8$ & 3,1 & $1,4-6,6$ \\
\hline
\end{tabular}

\section{Pembahasan}

Kematian neonatal masih merupakan masalah yang serius baik di negara maju maupun yang sedang berkembang. Angka kematian bayi di dunia sudah dapat diturunkan jauh lebih cepat dari angka kematian neonatus. Salah satu penyebab kematian neonatus yang sulit dikendalikan adalah berat lahir rendah atau prematuritas. Hasil penelitian kami menunjukkan angka kematian BBLSR 37,7\%. Beberapa penelitian terdahulu di negara berkembang mendapatkan angka kematian berkisar 16\%-57\% (2,6-10). Di rumah sakit rujukan tingkat tersier negara maju seperti Belanda, angka kematian BBLER dalam satu dekade turun secara dramatis dari $25 \%$ pada tahun 1983 menjadi $10 \%$ pada tahun $1995 .{ }^{3}$

Berat lahir sudah terbukti menjadi faktor prognostik kematian neonatus. Kami mendapatkan angka kematian bayi berat lahir $<1000 \mathrm{~g}$ masih jauh lebih tinggi $(60,7 \%)$ dibandingkan dengan bayi dengan berat lahir 1000 - $1500 \mathrm{~g}$ (30\%). Bayi yang lahir dengan berat badan di bawah $600 \mathrm{~g}$ belum ada yang bisa diselamatkan. Beberapa penelitian yang dilakukan di negara berkembang mendapatkan hasil angka kematian bayi berat lahir $<1000 \mathrm{~g}$ antara $48-68 \% .^{6,11,12}$

Nilai Apgar menit pertama kurang dari 4 merupakan prediktor yang cukup kuat untuk kematian BBLSR, temuan ini sesuai dengan penelitian sebelumnya. ${ }^{4}$ 
Disayangkan tidak semua bayi rujukan mempunyai data nilai Apgar saat lahir, di antara 134 kasus rujukan 38 (28\%) bayi tidak mempunyai nilai Apgar.

Infeksi terbukti merupakan salah satu faktor prediktor kematian pada BBLSR. BBLSR mempunyai risiko untuk terkena infeksi 2,7 kali lebih tinggi dibandingkan bayi dengan berat lahir normal. Kondisi ini terjadi karena sistem imun dan barier kulit BBLSR masih belum berkembang sempurna dan diperberat dengan tindakan invasif diagnosis dan terapi yang lebih sering dilakukan pada BBLSR. ${ }^{12,13}$ Kami menemukan BBLSR dengan sepsis mempunyai risiko kematian jauh lebih tinggi, sesuai dengan penelitian sebelumnya oleh Pereira dkk di Brazil. ${ }^{12}$

Penggunaan ventilator tidak dapat dipisahkan dengan kejadian infeksi, terutama ventilator-associated pneumonia (VAP). Penelitian sebelumnya menunjukkan BBLSR lebih berisiko untuk menderita VAP dibandingkan bayi lainnya, karena BBLSR mendapatkan terapi oksigen dengan ventilator lebih lama dibandingkan bayi dengan berat lahir normal. ${ }^{14}$

Kasus rujukan BBLSR cukup tinggi (37\%), menunjukkan risiko mengalami kematian tiga kali dibandingkan BBLSR yang lahir di RS Sardjito. Kondisi ini dapat dicegah dengan meningkatkan pengetahuan ibu hamil tentang tanda-tanda persalinan dan kapan harus segera mencari pertolongan. Penelitian sebelumnya juga menunjukkan bahwa kasus rujukan memang merupakan faktor risiko terjadinya kematian BBLSR. ${ }^{11}$

Disimpulkan bahwa selain berat lahir yang sudah secara konsisten terbukti sebagai faktor risiko kematian BBLSR, tingkat kesakitan, seperti nilai Apgar menit pertama $<4$, dan sepsis juga terbukti meningkatkan risiko kematian. Penggunaan ventilator juga meningkatkan kematian, karena kemungkinan bayi yang memerlukan ventilator adalah bayi yang sudah sakit parah. Sistem rujukan ternyata juga sangat penting untuk diperhatikan, karena bayi rujukan mempunyai risiko yang lebih tinggi untuk meninggal.

\section{Daftar pustaka}

1. Koops BL, Morgan LJ, Battaglia FC. Neonatal mortality risk in relation to birth weight and gestational age: update. J Pediatr 1982;101:969-77.
2. Trotman H, Bell Y. Neonatal sepsis in very low birthweight infants at the University Hospital of the West Indies. West Indian Med J 2006;55:165-9.

3. Anthony S, Ouden L, Brand R, Verloove-Vanhorick P, Gravenhorst JB. Changes in perinatal care and survival in very preterm and extremely preterm infants in The Netherlands between 1983 and 1995. Eur J Obstet Gynecol Reprod Biol 2004;112:170-7.

4. Kaiser JR, Tilford JM, Simpson PM, Salhab WA, Rosenfeld CR. Hospital survival of very low birth weight neonates from 1997 to 2000. J Perinatol 2004;24:343-50.

5. Richardson DK, Phibbs CS, Gray JE, McCormick MC, Workman-Daniels K, Goldmann DA. Birth weight and illness severity: independent predictors of neonatal mortality. Pediatrics 1993;91:969-75.

6. Velaphi SC, Mokhachane M, Mphahlele RM, BeckhArnold E, Kuwnda ML, Cooper PA. Survival of verylow-birth-weight infants according to birth weight and gestational age in a public hospital. S Afr Med J 2005;95:504-9.

7. Basu S, Rathore P, Bhatia BD. Predictors of mortality in very low birth weight neonates in India. Singapore Med J 2008;49:556-60.

8. Ho JJ, Chang AS. Changes in the process of care and outcome over a 10-year period in a neonatal nursery in developing country. J Trop Pediatr 2007;53:232-7.

9. Sritipsukho $S$, Suarod T, Sritipsukho P. Survival and outcome of very low birth weight infants born in a university hospital with level II NICU. J Med Assoc Thai 2007;90:1323-9.

10. de Almaida MF, Guinsburg R, Martinez FE, Procianoy RS, Leone CR, Marba ST dkk. Perinatal factors associated with early deaths of preterm infants born in Brazillian network on neonatal research centers. J Pediatr (Rio J) 2008;84:300-7.

11. Ballot DE, Chirwa TF, Cooper PA. Determinants of survival in very low birth weight neonates in a public sector hospital in Johannesburg. BMC Pediatrics 2010;10:30-41.

12. Pereira SMP, Cardoso MHC, Figuexeds AL, Mattos H, Rozembaum R, Ferreira VI, dkk. Sepsis-releted mortality of very low birth weight Brazillian infants: the role of Pseudomonas aeruginosa. Int J Pediatr 2009;2009:1-6.

13. Makhoul IR, Sujov P, Smolkin T, Lusky A, ReichmanB. Pathogen-specific early mortality in very low birth weight infants with late-onset sepsis: a national survey. Clin Infect Dis 2005:40:218-24.

14. Foglia E, Meier MD, Elward A. Ventilator-associated pneumonia in neonatal and pediatrics intensive care unit patients. Clin Microbiol rev 2007;20:409-25. 